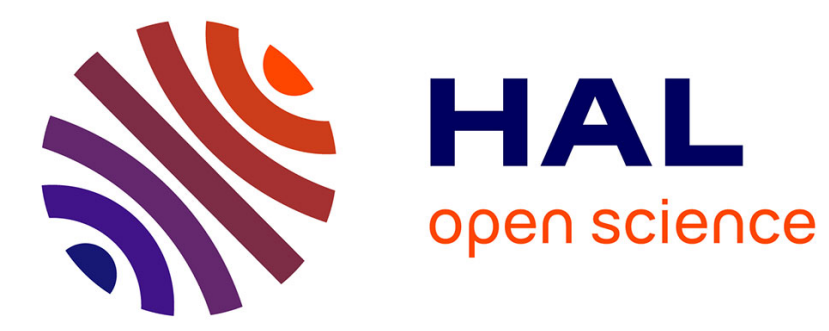

\title{
Impurities and oxygen control in lead alloys
}

\author{
J.-L. Courouau, P. Trabuc, G. Laplanche, Ph. Deloffre, P. Taraud, M. \\ Ollivier, R. Adriano, S. Trambaud
}

\section{To cite this version:}

J.-L. Courouau, P. Trabuc, G. Laplanche, Ph. Deloffre, P. Taraud, et al.. Impurities and oxygen control in lead alloys. Journal of Nuclear Materials, 2002, 301 (1), pp.53-59. 10.1016/S00223115(01)00726-7 . cea-02872383

\section{HAL Id: cea-02872383 https://hal-cea.archives-ouvertes.fr/cea-02872383}

Submitted on 17 Jun 2020

HAL is a multi-disciplinary open access archive for the deposit and dissemination of scientific research documents, whether they are published or not. The documents may come from teaching and research institutions in France or abroad, or from public or private research centers.
L'archive ouverte pluridisciplinaire HAL, est destinée au dépôt et à la diffusion de documents scientifiques de niveau recherche, publiés ou non, émanant des établissements d'enseignement et de recherche français ou étrangers, des laboratoires publics ou privés. 


\title{
Post print
}

Courouau, J. -L., P. Trabuc, G. Laplanche, Ph. Deloffre, P. Taraud, M. Ollivier, R. Adriano, et S.

Trambaud. « Impurities and Oxygen Control in Lead Alloys ». Journal of Nuclear Materials 301, n 1 (1

février 2002): 53-59. https://doi.org/10.1016/S0022-3115(01)00726-7

\section{Impurities and oxygen control in lead alloys}

\author{
J.-L. Courouau ${ }^{\text {a, }}$, P. Trabuc ${ }^{a}$, G. Laplanche ${ }^{a}, \mathrm{Ph}$. Deloffre ${ }^{\text {b }}$, P. Taraud ${ }^{\text {a }}$, \\ M. Ollivier ${ }^{\mathrm{a}}, \mathrm{R}$. Adriano ${ }^{\mathrm{a}}, \mathrm{S}$. Trambaud ${ }^{\mathrm{a}}$

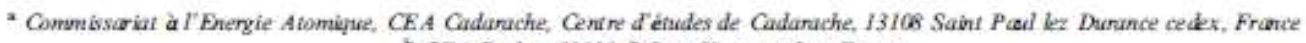 \\ bEA Saclay, 91191 Gif sur Ytette cedex, Fnance
}

\begin{abstract}
The control of the impurities is of major interest for ensuring adequate and safe operation of lead alloys facilities from the viewpoint of the corrosion phenomenon. Specific methods have to be implemented for effective control of the liquid kad-bismuth eutectic quality to the required specifications, as for instance: dissolved oxygen monitoring, dip. sampling system, analytical techniques for impurities measurement. Even though the oxygen control in the static facility BIP proved difficalt, a better knowledge of kinetics behaviour of the oxygen is acquired. Oxygen sensors gave results in agreement with the theory during the tests achieved on the BIP and on the COLIMESTA facilities. The dip sampler was validated on static device: it allows an effoctive sampling of the liquid metal melt and an easy separation of the melt from the sampling device when cold. The set of analytical techniques for the measurements of metallic impurities is efficient as well, except for the nickel element, for which the method of analysis with atomic absorption spectroscopy coupled with spiking method should allow the lower detection limit to be decreased below the $5 \mu \mathrm{g} g$ as for the iron impurity,
\end{abstract}

\section{Introduction}

Lead and lead-bismuth eutectic (LBE) are studied worldwide as spallation targets in accelerator driven system (ADS), in which high energy protons collide with lead throughout a window to produce 15-20 fast neutrons by the spallation reaction. These neutrons might be usad either in sub-critical power reactor systems, that present an intrinsic safety quality, or in the long-lived actinides transmutation system in the framework of the nuckar waste management. The latter option is currently under study in France within the 1991 law on nuckear wastes management. Besides, the lead alloy can be used as a primary coolant, but unlike the hiquid sodium, used as coolant in fast reactors worldwide, lead alloys are not compatible with any sted, inducing spe-

\footnotetext{
Corresponding author. Tel, $+33-442253266$, fax: $+33-4$ 42257287 .

E-mail addess: jean-louis.courousuräoea.fr (J,-L. Colsrouau).
}

cific requirements for corrosion protection implementation and for liquid metal quality control, in order to ensure adequate and safe operations. The control of oxygen and impurities in LBE is then a challenge for both corrosion control (ensure steel protation,...) and quality control (avoid shg's formation, himit circuits contamination,...), that is one of the key issue for any lead alloy system. Spexific methods must be implemented for the effective control of the liquid LBE quality to meet the required specifications, such as dissolved oxygen monitoring, dip sampling system, and anabytical techniques for impurities measurements.

\section{Oxygen monitoring in kad-bismuth eutectic}

A typical electrochemical cell puts in contact two different media throughout a solid electrolytic bridge which presents pure ionic conduction. One of the media is called the reference, as its function is to provide a constant oxygen thermodynamic activity. The other is the liquid LBE, for which the dissolved oxygen 


\section{Post print}

Courouau, J. -L., P. Trabuc, G. Laplanche, Ph. Deloffre, P. Taraud, M. Ollivier, R. Adriano, et S.

Trambaud. "Impurities and Oxygen Control in Lead Alloys ". Journal of Nuclear Materials $301, n^{\circ} 1$ (1 février 2002): 53-59. https://doi.org/10.1016/S0022-3115(01)00726-7

concentration is to be measured. The solid electrolyte is made of ceramic in the form of a thimble that specifically conducts the axygen ions such as yttria stabilised zirconia (YSZ) or mannesia stubihsed zirconia (MSZ). Starting from the liquid sodium experimental foedback for axygen sensors operating at low temperature (350$\left.500{ }^{\circ} \mathrm{C}\right)[1-3,9]$, the objective of first experiments in LBE melt is to verify the prototype sensors behaviour with regards to;

- The use of zirconia instead of the fragile thoria that was usod for the liquid sodium at low temperature (lower electrolytic domain boundary) [4-7];

- The operating temperature, as for instance the interfacial resistance between the ceramic and the internal reference (mujor contribution of the overall cell resistance) is increasing with lowering temperature that eventually prevent any measurement [11];

- The compatibility of the ceramic with the LBE melt and with the internal reference, that determines the sensor hfe time [11].

First experiments can be made in static facilities. Ultimately, selected prototype sensors should be tested on dynamic facilities in order to provide real operating conditions to fully validate the sensors (time drift. thermal operating shocks, calibration possibilities, long term operation,...).

\subsection{Theoretioal formulation}

For the dissolved oxygen concentration, the hypothesis of an ideal solution is often made [8], and the Henry's law is applied to the solute oxygen. Assuming solid kad monoxide as the standard state for the oxygen in LBE [8], the oxygen activity shall be equal to unity when saturation is made:

$a_{0}=\frac{C_{b}}{C_{0}}$

where $C_{0}$ is the dissolved oxygen concentration and $C_{0}$ is the saturated oxygen concentration expressed in weight percent.

The general relationship for a metal-metal oxide (M/ $\mathrm{M}_{i \mathrm{M}} \mathrm{O}_{\infty}$ ) reference is derived from the Nernst relation, assuming a pure ionic conduction of the solid electrolyte (reversible cell):

$$
\begin{aligned}
& E_{\text {saturdoe }[\mathrm{V}\}}=\frac{1}{2 F}\left(-\frac{x}{V_{0}}+d-R a\right) \\
& +\frac{1}{2 F}\left(\frac{y}{v_{0}}-b^{\prime}-R b\right) T_{(K)} . \\
& E_{(\mathrm{v})}=\frac{1}{2 F}\left(-\frac{x}{v_{0}}+a^{\prime}-R a-R B\right) \\
& +\frac{1}{2 F}\left(\frac{y}{v_{0}}-b^{\prime}-R b+R A\right) T_{\{\mathrm{K}\}} \\
& -\frac{R}{2 F} T_{(\mathrm{K})} \ln C_{(\mathrm{o} / \mathrm{WA} / \mathrm{K})}
\end{aligned}
$$

with $R$ the perfect gas constant $(8.31441 \mathrm{~J} / \mathrm{mol} / \mathrm{K})$ and $F$ the Faraday constant $(96484,6 \mathrm{C} / \mathrm{mol})$.

All constants are defined in the following relationships. Saturated oxygen concentration (7) $\ln C_{\text {o(ws) } 5)}=$ $A-\left(B / T_{(\mathrm{K})}\right)$ with $A=2.7631$ and $B=7828.789$; Lead activity in LBE [7]: $\ln a_{\mathrm{Pb}_{\mathrm{o}}}=-\left(a / T_{(\mathrm{K})}\right)-b$ with $a=$ 135.21 and $b=0.8598$. Standard Gibb's energy of $\mathrm{PbO}$ formation [10]: $\Delta_{f} G_{\mathrm{P}, 0 y / a b l]}=-d+b T_{(\mathrm{K})}$ with $d=$ 218936 and $b^{\prime}=99.412$ for $298<T<1159 \mathrm{~K}$. Standard Gibb's energy of the $\mathrm{M}_{z} \mathrm{M}_{m}$ oxide formation: $\Delta_{f}$ $G_{\mathrm{M} \text { Ma }}^{\circ}(1 /$ moll $)=-x+y T_{(\kappa)}$. Thermodynamic table $[10]$ gives the values for the different referenoe systems:

$$
\begin{aligned}
& A_{f} G_{\text {son }}^{\circ}[\mathrm{J} / \mathrm{mol} \\
& \text { for } 298<T<1800 \mathrm{~K},
\end{aligned}
$$

\begin{tabular}{|c|c|c|c|c|c|c|}
\hline & $\kappa$ & $K^{\prime}$ & $\kappa_{i}$ & $K_{2}$ & $K_{s}$ & Melting $T\left({ }^{\circ} \mathrm{C}\right)$ \\
\hline $\mathrm{PbO}$ & $-0,006$ & $-3.705 E-05$ & $-0,343$ & $8.201 \mathrm{E}-05$ & $-4.309 \mathrm{E}-05$ & 327 \\
\hline $\mathrm{SnO}_{2}$ & $-0,377$ & $-1.542 \mathrm{E}-05$ & -0.715 & $1.036 E-04$ & $-4.309 \mathrm{E}-05$ & 232 \\
\hline $\mathrm{In}_{2} \mathrm{O}_{3}$ & $-0,469$ & $6.354 \mathrm{E}-07$ & -0.806 & $1.197 \mathrm{E}-04$ & $-4.309 \mathrm{E}-05$ & 157 \\
\hline $\mathrm{Bi}_{2} \mathrm{O}_{3}$ & 0.128 & $-6,368 \mathrm{E}-05$ & -0.210 & $5.538 \mathrm{E}-05$ & $-4.309 \mathrm{E}-05$ & 271 \\
\hline Aif $\mathrm{Pl}$ & 1.129 & $-5.858 \mathrm{E}-04$ & 0.791 & $-4.668 \mathrm{E}-04$ & $-4.309 \mathrm{E}-05$ & - \\
\hline
\end{tabular}

$$
\begin{aligned}
& \Delta_{f} G_{\mathrm{h}_{2} \mathrm{O}_{1}(\mathrm{~J} / \mathrm{mol})}^{\infty}=-925021+320.05 \mathrm{~T}_{\mathrm{K})} \\
& \text { for } 298<T<1600 \mathrm{~K} \text {, } \\
& \Delta_{f} G_{\mathrm{R}_{2} \mathrm{O},[\mathrm{J} / \mathrm{mil})}=-579466+282.82 T_{[\mathrm{K})} \\
& \text { for } 298<T<1003 \mathrm{~K} \text {. }
\end{aligned}
$$

The two relationships can be identified to the following relations defining the relevant constants:

$E_{\text {aharisoe }(\mathrm{V})}=K+K^{\prime} T_{(\mathrm{K})}$ and

$E_{(\mathrm{V})}=K_{1}+K_{2} T_{(\mathrm{K})}+K_{3} T_{(\mathrm{K})} \ln C_{\mathrm{o}(\mathrm{W} / \mathrm{h})}$ :

Table 1

Numerical values of constants for the theoretical emf. relations for variots reference systems 


\section{Post print}

Courouau, J. -L., P. Trabuc, G. Laplanche, Ph. Deloffre, P. Taraud, M. Ollivier, R. Adriano, et S.

Trambaud. « Impurities and Oxygen Control in Lead Alloys ». Journal of Nuclear Materials $301, n^{\circ} 1$ (1 février 2002): 53-59. https://doi.org/10.1016/S0022-3115(01)00726-7

Numerical value for some reference systems are given in Table 1. Graphical presentation can be made expressing the emf, values versus temperature, taking the oxygen concentration as a parameter [12]. This representation allows a rapid interpretation of signal output from oxygen probes. This kind of graphic is usad in Figs. 1 and 2. Theoretical emf, values start at the melting temperature of the reference, which defmes the bwer operating temperature for the oxygen sensors, assuming that there is no electrical contact below this temperature.

\subsection{Sensors tested}

Up to now, five prototype sensors were tested: four of them were provided by the Heraeus Eloctro-nite Company (HEN) (sensor nos. 1-3 and 5) and built from the model of the Harwell sensor type MK2A, largely used in liquid sodium facilities, with the standard materiak used by HEN ( $75 \mathrm{~mm}$ height, $6.5 \mathrm{~mm}$ outside diameter, 1.5 mm thickness). The last one was built on purpose using commercial Degussa YSZ (35 mm height, $9 \mathrm{~mm}$ outside diameter, $1.5 \mathrm{~mm}$ thickness). The sensors are described as follows:

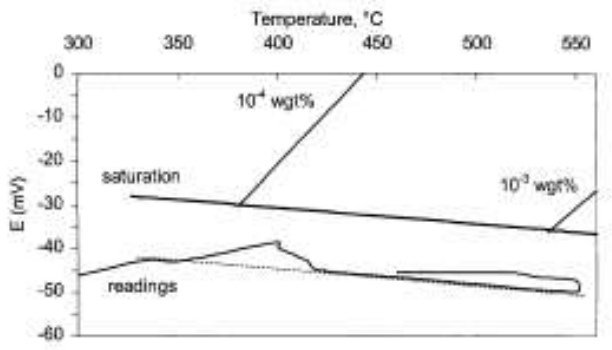

Fig. 1. Results obtained with sensor no. 1 in LBE melt in the BIP facility with oxygen concentration in w1\% as parameter.

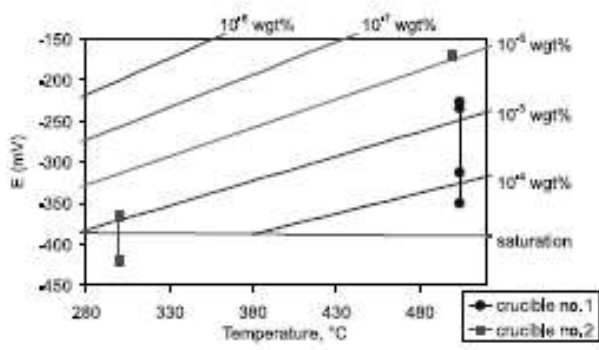

Fig. 2, Results obtained with sensor no. 5 in LBE melt in the COLIMESTA facility with oxygen concentration in wt as parameter.
- nos. 1-3: steel wire (earth)/LBE-PbO//YSZ/Pb-PbO/ Re wire, no, 1 is protected by a SS304 sheath:

- no. 4: steel wire (earth)/LBE-PbO//YSZ//Bi- $\mathrm{Bi}_{2} \mathrm{O}_{3} /$ Mo wire;

- no. 5: steel wire (earth)/LBE-PbO//MSZ//Sn-SnO $2 /$ Re wire, SS304 sheath.

All measurements are made with a high impedance voltmeter $\left(10^{12} \Omega\right)$ : PH-meter Tacussel PHN81.

\subsection{Static facilities}

Experiments were mainly carried out on the static crucible (100 mm diameter, $80 \mathrm{~mm}$ height, SS316 steel) facility called BIP $[9]$ which enables to work with a limited amount of LBE mett (around $6 \mathrm{~kg}$ ), at a controlled temperature and with a controlled cover gas. It was recently improved in order to implement up to four sensors at the same time, and to introduce gas throughout a bubbler ( $8 \mathrm{~cm}$ diameter toric bubbler). This facility is coupled to a ternary gaseous mixture system, which allows the preparation of steam, hydrogen and argon with defined ratio of water to hydrogen (from 100 to $10^{6}$ ). Melting procedure for the preparation of the LBE melt is as follows: first melt in a glove box (argon) after a careful deaning and brushing of ingots, removal of the remaining oxides, cooling and transfer to the static facility when solid. Other measurements were achieved in the COLIMESTA facility [13], which was used for long term corrosion experiments in static crucibles (SS316 steel) at defined temperature and under purified argon cover gas.

\subsection{BIP resilts}

A test campaign was carried out in the Bip Facility for 15 days at the end of the year 2000 with the sensor nos, 1-4. The initial operating conditions were as follows: bubbling of a reductive gas mixture $(0,256 \mathrm{l} / \mathrm{min}$ of $\mathrm{Ar}+4 \% \mathrm{H}_{2}$ then $1 \mathrm{l} / \mathrm{min}$ of $\mathrm{Ar}+4 \% \mathrm{H}_{2}$ ). Then, a ternary gas mixture composed of argon ( $1 \mathrm{l} / \mathrm{min}$ ), $\mathrm{Ar}+4 \% \mathrm{H}_{2}$ $(0.052 \mathrm{l} / \mathrm{min})$ and steam $(100 \mathrm{~g} / \mathrm{h})$ was bubbled in the facility: this defines a dissolved oxygen activity of $10^{-5}$ wt $\%$ at $5900^{\circ} \mathrm{C}(0.1 \mu \mathrm{g} / \mathrm{g})$ according to the water to hydrogen molar ratio of 1000 . In practice, the quality control for this pexuliar set of experiments showed odd effects. During the first week of the experiment, there was only a thin film of oxide covering part of the froe level of the liquid metal, which appeared constant in area during this period. After about seven days, whik the cover gas was still a reductive gas mixture of argon with hydrogen, a thick layer of powder deposited on the free liquid level, most probably because of an inkt of air back thr ough the discharge line caused by a break in the feeding argon line. A lot of aerosols were also observed stuck on all the internal parts of the facility. Bubbling of 
diluted hydrogen in argon for a few days had no effect on that pollution. The water-hydrogen-argon gaseous mixture was then put in operation, in order to determine the possibility to obtain under-saturated solution, even in spite of the presence of solid axides. The bubbling of the ternary mixture worsened the pollution of the facility, as the quantities involved in the pollution increased tremendously. Indead, the quantities of deposits on the structural surfaces of the facility were large: thickness up to $2 \mathrm{~cm}$, composed mainly of lead mono-oxides (Yellow or Red phases) with a relative built up of pure bismuth. The mass of the lead-bismuth melt in the crucible decreased by $1.7 \mathrm{~kg}$.

Two interpretations of this poor oxygen control may be proposad: conceptual and operating defaults of the vent line and kinetics related probkern. The former is associated to the absence of a discharge valve, that eventually caused an air ingress when the argon feeding gas bottk went empty at one moment or when the gas flow rate was too low. The latter is associated to the bubbling of gases: the steam oxidation kinetic of the LBE melt appears to be faster than the hydrogen reduction kinetic. Indeed, the kad oxide were preferentully produced, while the water to hydrogen molur ratio should have prevented any oxides formation. For a better control of the oxygen with this technique, it would have been better to re-circulate with the strictly required amount of gases for any concentration change when bubbling. Another option is to control only the cover gas composition in order to control the dissolved oxygen concentration: kinetics are then fimited by the small exchange area of the free level, favouring the thermodynamic equilibrium. As a condusion of the oxygen control for this set of experiments, the LBE must have been saturated over the whole operating time. This conclusion is confirmed with the metallur gical analysis of a slice of the cruable, which shows a relatively thick oxide hyer between the sted and LBE melt up to a $1 \mathrm{~cm}$ depth, and shows no wettability of the LBE melt with the steel crucible downwards due to thinner oxides layers.

The four sensors were immersed in the lead-bismuth melt as soon as the metal was liquid. The probe no. 1, which is the only one protected with a metallic sheath, gave a voltage response over the whole operating time, whereas the other probes showed limited life time: 6 days for no, 2, $2 \mathrm{~h}$ for no. 3, and a few minutes for no. 4 . The cause of the early breakdown of the latter probe is most probably the little height of the ceramic thimble used (35 $\mathrm{mm}$ ), that puts high thermal stresses on the ceramic putty (Cotronics's alumina based ceramic cement) used to seal the internal metal/metal oxide reference. When the first three sensors operated simultaneously, all of them gave roughly identical responses. The plots of the emf. versus operating temperature for sensor no, 1 are shown in Fig. 1, where the theoretical saturated and unsaturated lines are also plotted. All the experimental values are close to the theoretical saturated line, with a shift of $-14 \mathrm{mV}$, which is small considering all possibilities of thermocouple effects at the various electrical connections from the probe to the PH-meter. These possible effects will be taken into account in a later stage of development. The slope of the experimental curve is equal to the theoretical one for a temperature range of $330-550{ }^{\circ} \mathrm{C}$. However for temperatures lying between 350 and $420^{\circ} \mathrm{C}$ an unexplained hittle peak is observat ( $5 \mathrm{mV}$ deviation). When decreasing temperature, the curve is somewhat different (kinetic effect at cooling). Besides, time to response to a temperature shift is very rapid. The results of the sensor no. 1 ower the 15 days of operation showed very stable emf. value, considering all temperature changes and operating conditions disturbances.

After the experiments, HEN's YSZ broken œramics showed very poor mechanical resistance. This was confirmed by optical and electronic microscopy analyses. No trace of corrosion were detected, but multiple cracks on the HEN's YSZ, whereas only few cracks were detected on the Degussa's YSZ. The reason for that difference may be the open porosity which is null for the Degussa and equal to a few percent for the HEN YSZ.

As a conclusion, proximity of the ceramic with the cold bubbling gas comparal to LBE temperature ( 300$)$ ${ }^{\circ} \mathrm{C}$ gradient at kast) caused thermo-mechanical stresses on the ceramic, that eventually lead to the breakdown. The metallic sheath implemented on the probe no, 1 appeared very useful from this point of view. Probes are behaving according to the theory, even showing the possibility of a measurement down to $330^{\circ} \mathrm{C}$, with a relative stability over 2 weeks. Experiments are to be continued with better oxygen control in the facility with no bubbling and possibly with metallic sheath for protextion of probes.

\subsection{COLIMESTA rexultis}

When the COLIMESTA long term experiments started, early 2000 , the opportunity was taken to measure the oxygen content with probe no. 5 : measurements are reported on Fig. 2. First the probe was immersed in $504{ }^{\circ} \mathrm{C}$ LBE melt, and gave $-350 \mathrm{mV}$ response for 2 $\mathrm{min}$, and then $-226 \mathrm{mV}$ stable. Probe was then removed, and re-immersed in the bath: $-316 \mathrm{mV}$ were read for a few moment and then $-234 \mathrm{mV}$ stable were read for hours. This may be explained by the oxide layer formed on the ceramic thimble due to transport in open air, which oxides (lead and bismuth oxides) are dissolved immediately after immersion. Indeed, a reading close to $-350 \mathrm{mV}$ indica tes saturation, whereas the stable readings indicate a bath under saturated at about $10^{-5} \mathrm{wt} \%$ $(0.1 \mu \mathrm{g} / \mathrm{g})$ according to the theoretical line. The sensor was then inserted in the second bath at a temperature of $300^{\circ} \mathrm{C}$ : reading gave -365 to $-430 \mathrm{mV}$ unstable. A very 


\section{Post print}

Courouau, J. -L., P. Trabuc, G. Laplanche, Ph. Deloffre, P. Taraud, M. Ollivier, R. Adriano, et S.

Trambaud. "Impurities and Oxygen Control in Lead Alloys ". Journal of Nuclear Materials $301, n^{\circ} 1$ (1 février 2002): 53-59. https://doi.org/10.1016/S0022-3115(01)00726-7

poor wettability was observed between ceramic and liquid melt. The temperature was then increased to 500 ${ }^{\circ} \mathrm{C}$, but unfortunately with no data recording. When reaching the $400^{\circ} \mathrm{C}$ temperature, readings went stable, indicating the wettability transition. At $500^{\circ} \mathrm{C}$, readings were stable for 3 days at $-170 \mathrm{mV}$, corresponding to $10^{-6} \mathrm{wt} \%(0.01 \mu \mathrm{g} / \mathrm{g})$ according to the theoretical plots. Then, readings decreased regularly to a null value, which is significant of a typical failure mode of this kind of sensor. This may be causal by an electrical short-cut in the solid electrolyte, caused either by corrosion or by insertion of liquid metul in the solid elextrolyte. Another cause may be the corrosion of the $\$ \$ 304$ sheath, which deposited a growing oxide byer on the YSZ interface, increasing the interfacial cell impedance that eventually cancelled the emf. As a conclusion, no. 5 sens or behaved in agrecment with the theoretical lines, but calibration of the emf. with axygen concentration measurement is necded to confirm any conclusion.

\section{Dip sampler validation}

The objective is to be able to take a sample of liquid LBE in any facility through an air bok to perform subsequent chemical analysis with the following required specifications for the sampling system: sample homogeneous and fluid liquid metal; a system that does not pollute liquid metal sample; a system which is easy to operate, as it is required to operate in a nuclear envir onment; a system that may be quickly cooled. Such device has already been developed for the lead-lithium related technologies. The basic principle was to adapt the sampling system to the LBE melt and achieve a first qualification on a static facility in saturated conditions. A view of this dip sampler developed for the lead-lithium alloys is provided in Fig. 3. The tube on the bottom part, opposite to the hole for the inlet of the melt, was necessary to ensure a good filling of the sampler by enabling out gassing. This tube is no more needed for leadbismuth alloy, because of its density. The dip sampler fabrication is thus simplified. The nature of the alloy used is stainless steel. The stripy marks done during fabrication on the external surface of the dip sampler enable a very easy discarding of the steel, like the

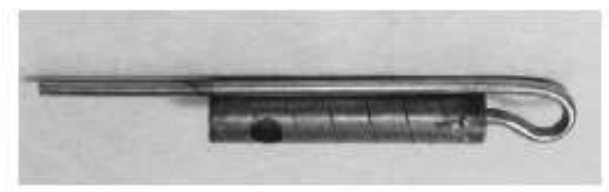

Fig. 3. View of the dip sampler ( $92 \mathrm{~mm}$ length, $12 \mathrm{~mm}$ outside diameter). opening of a tin, delivering the LBE sample ready for its analysis.

\section{Chemical analysis of kad-bismuth eutectic}

Various techniques are used for kad alloy characterization, as follows: composition analysis; metallic impurities characterization; oxygen present in the alloy measurement. The composition analysis techniques are based on calorimetry, surface spectroscopy analysis, or atomic absorption spectroscopy (AAS). The calorimetric method principle is to measure the thermal flux absorbed or produced by a sample subjected to a temperature increase. The results enable to deduce the respective reaction temperature, the eutectic and peritectic points, as well as the reaction specific heat. But this kind of analysis is not sufficient by itself as several compositions are often possible when referring to a phase diagram. The surface spectroscopy analysis consists of $\mathrm{X}$-ray analysis, scanning ekctron microscopy (SEM), or wavelength dispersive X-ray fluorescence (WDXRF). When energy dispersive $\mathrm{X}$-ray spectrometer (EDS) is couplat to a scanning ekctron microscope, the measure of the alloys composition is possible in any point of the sample. Mean value of several points (10 at kast) could be used to determine the mean composition of the alloys. The scanning eketron microscope enables the general state of the alloys to be determined, through the study of its enriched or depleted zone. The WDXRF method enables the measurement of virtually all the Periodic Table $(Z>11)$ for concentrations above 500 $\mu \mathrm{g} / \mathrm{g}$. This method is thus well adapted to the alloys compasition determination, but not for any impurities measurement. The metallic impurities analyses are achieved first by dissolution of the lead alloy, and then by the use of inductive coupled plasma-mass spectrometry (ICP/MS) or AAS. The ICP/MS method enables the measurement of a wide range of impurities such as $\mathrm{Fe}, \mathrm{Ni}, \mathrm{Cr}, \mathrm{Ag}, \mathrm{Cd}, \mathrm{Cu}, \mathrm{Sn}, \mathrm{Sb}, \ldots$. The iron impurity has an isobaric interference with $\mathrm{ArO}$ gaseous mixture (Ar being the plasma gas), that increases the lower detection timit to $50 \mu \mathrm{g} / \mathrm{g}$. For the iron impurity, the AAS technique coupled with the spiking method is then a better choice than the ICP-MS technique, resulting in a bower detection limit decreased to $5 \mu \mathrm{g} / \mathrm{g}$. For the nickel impurity, because of the pollution coming from the nickel cones of the transfer chamber of the ICP-MS apparatus, the lower detection limit is high when compared to the other impurities. There are two methods for decreasing the lower detection limit: changing the cones to platimum cones, or measuring nickel by AAS with spiking method as for the iron. The analytical measurement of oxygen in a sample can be made using two methods, both of which measure the total amount of oxygen present in the alloys: either the 


\section{Post print}

Courouau, J. -L., P. Trabuc, G. Laplanche, Ph. Deloffre, P. Taraud, M. Ollivier, R. Adriano, et S.

Trambaud. « Impurities and Oxygen Control in Lead Alloys ». Journal of Nuclear Materials $301, n^{\circ} 1$ (1 février 2002): 53-59. https://doi.org/10.1016/S0022-3115(01)00726-7

dissolved oxygen and the oxides. The first method is based on the reductive fusion of the sample in a graphite crucible. The resulting carbon dioxide is measured by infra-red spectroscopy. This technique is used with careful calibration in the expected range, and with devoted preparation procedures for the sample in order to reduoc any superficial axide. The other method is based on electrochemical measurement as described above with baboratory scale elearochemical cells.

The alloy composition measured in the LBE supplied by Metaleurop is: $41.7 \pm 2 \mathrm{wt}^{\mathrm{t}} \%$ of lead and $57.3 \pm 2$ wt $\%$ of bismuth (WDXRF). The alloy fusion temperature is measured by calorimetry: $126.2^{\circ} \mathrm{C}$. During the cooling phase of the dip sumpling, a segregation phenomenon happens, resulting in a relative heterogeneity of the lead alloy depending on the method used for composition characterization. Typically, a better composition measurement is obtamed by dissolution of the whole sample, than on parts of the sample. The impurities measured by ICP-MS except for the iron (AAS) are as follows: $\mathrm{Sn}(<2 \mu \mathrm{g} / \mathrm{g}) ; \mathrm{Fe}(<5 \mu \mathrm{g} / \mathrm{g}) ; \mathrm{Ni}(<20$ $\mu g / g) ; A g(3 \mu g / g) ; C u(<2 \mu g / g) ; \mathrm{Zn}(<2 \mu g / g) ; C d$ $(<1 \mu g / g) ; \mathrm{Sb} \quad(<2 \mu \mathrm{g} / \mathrm{g}) ;$ As $(<2 \mu \mathrm{g} / \mathrm{g}) ; \mathrm{Te}(<1 \mu \mathrm{g} / \mathrm{g})$. Theses values correspond to the lead and bismuth respective characterization before being mixed, except for the nickel, whose detection limit is to be improwed with AAS coupled with spiking method. The first tests for the oxygen measurement were made with a LECO apparatus calibrated with steel matrix giving thus a different fusion temperature. The results showed dispersed values for the lead alloy sumple: from 1 to $5 \mu \mathrm{g} / \mathrm{g}$. A different approach based on calibration of the apparatus with a I $\mu \mathrm{g} / \mathrm{g}$ lead sample did not allow the detection limit to be lowered. Actually, the apparatus used for these measurements proved insufficient for this kind of study: background level of the LECO apparatus is too high and its resulting sensitivity appeared too low.

\section{Conclusions}

Even though the oxygen control in the static facility BIP proved difficult, some kinetic behaviour of the oxygen in LBE was acquired. Electrochemical oxygen sensors give results that are in agreement with the theory for the $\mathrm{Pb} / \mathrm{PbO}$ reference YSZ sensor (no. 1), as well as for the $\mathrm{Sn} / \mathrm{SnO}_{2}$ reference MSZ sensor (no. 5). More experimental results with control of dissolved oxygen are needed for any validation, as well as a calibration procedure to confirm the theoretical set of lines. Moreover, the hypothesis of thermo-mechanical stresses to explain the breakdown of three sensors out of four, secmingly confirmed through metallurgical analysis, has to be confirmad through long term experiments with no stresses of any kind, and no protective metaltic sheath.

IPPE and research centre Cadarache, The main impurities and their conditions in the $\mathrm{Pb}-\mathrm{Bi}$ coolant, Obninsk, 1998.

[8] H.U. Borgatedt, C.K. Mathews, Applied Chemistry of the Liquid Alkali Metals, Plenum Press, New York, 1987.

[9] J.L. Courouan, G. Laplanche, J. Desreumaux, C. Latge, Physico-chemistry of lead-bismuth eutectic: alloy characterisation and on-line oxygen-meter validation, European Workshop on Heavy Liquid Metal Technology for use in ADS, Forschungszentrum Karlsruhe, Germany, September, 1999.
The dip sampling system adapted from the leadlithium technology proved to be efficient in saturated conditions, but has to be confirmed in unsaturated bath for a full validation.

The set of analytical techniques for the measurement of metallic impurities is efficient as well, except for the nickel element, for which the method of analysis with AAS couplad with spiking method should allow the lower detection fimit to be decreased below the $5 \mu \mathrm{g} / \mathrm{g}$ as for the iron impurity.

All these techniques are to be implemented on a dy. namic fucility for long term operation and validation in typical operating conditions (Standard Technology Loop for Lead Alloys).

\section{Acknowledgements}

This work, which takes place within the CEA framework of the transmutation in hybrid system for the reduction of long-lived nuclear wastes, has been partly done with the support of the European Community under the fifth PCRD (TECLA group), whose support is acknowledgat.

The Heraeus Electro-nite company is as well acknowledged for its support in providing prototypes oxygen sensors, and for its helpful collaboration. P. Bernard from Houthalen, Belgium, and R. Conti, from Philadelphia, PA, USA, are gratefully acknowledgod.

\section{References}

[1] R.C. Asher, R.G. Taylor, The Harwell oxygen sensors, Description, operating conditions and performance, AERE-R 10812, revised 1986 (Instrumentation and Applied Physics Division, Harwell Laboratory),

[2] R.C. A sher, D.C. Harper, T.B.A. Kirstein, F. Leach, R.G. Taylor, Recent developments in the design, perfomance, and application of HAR WELL oxygen sensors and Harwell carbon meters, Fourth Internationsd Conferenoe on Liquid Metal Engineering and Technology, Avignon France, 17-21 October, 1988 (UKAEA).

[3] M.G. Barker, D.K. Chamberlain, S.A. Frankham, NJ. Moon, S.E. Smith, Flectrochemical measurements in liquid alkali metals, Fourth International Conference on Liquid Metal Fngineering and Technology, A vignon France, 1721 October, 1988 (University of Nottin gham, UK).

[4] G. Periaswami, S.R. Babu, C.K. Mathews, Development of a zirconia based oxygen monitor for sodium coolant, Fourth Intemational Conference on Liquid Metal Engneering and Technology, A vignon France, 17-21 Oetober, 1988 (Radiochemistry program, IGCAR, India).

[S] E. Sugimoto, S. Kuwata, Z. Kózuka, Nihon Kinzołcu Gakkai-shi 44 (6) (1980) 644 (in Japanese).

[6] E. Sugimoto, S. Kuwata, Z. Kózuka, Nihon Kogyokai-shi 97 (1125) (1981) 1199 (in Japanese).

[7] Y.I. Oriov, A.D. Efanov, V.M. Troyanov, Performance of works under con tract no. 501068 BQ 49630 between SSC R. F

[10] L. Barin, Thermochemical Data of Pure Substanoes, VCH Editions, Weinheim, Germany, 1989

[11] J.-L. Courouau, F. Masse, G. Rodriguer, C. Latge, B. Redon, The various sodium purification techniques, International Working Group on Fast Reactors, Aix-en-Proyence, France, 3-7 November, 1997.

[12] J. Konys, H. Muscher, Z, Voss, O, Wedemeyer, Development of oxygen meters for the use in lead bismuth, IWSMT, Schnm, Austria, October 2000.

[13] P. Deloffre, Ph. Deloffre, A. Terlain, F. Barbier, these Proceedings, p. 35. 